\title{
Preconcentration of Germanium(IV) on Styrene-Maleic Anhydride Copolymer Modified with Aminobenzoic Acids and Its Spectrophotometric Determination with Bis(2,3,4-trihydroxyphenylazo)benzidine
}

\author{
Kamran T. Mahmudov ${ }^{1,2^{*}}$, Rafiga A. Aliyeva ${ }^{1}$, Sahil Z. Hamidov ${ }^{1}$, Famil M. Chyragov ${ }^{1}$, \\ Samira R. Mardanova ${ }^{1}$, Maximilian N. Kopylovich ${ }^{2}$, Armando J. L. Pombeiro ${ }^{2 *}$ \\ ${ }^{1}$ Department of Chemistry, Baku State University, Baku, Azerbaijan \\ ${ }^{2}$ Centro de Química Estrutural, Complexo I, Instituto Superior Técnico, Technical University of Lisbon, Lisbon, Portugal \\ Email: *kamran_chem@yahoo.com, ${ }^{*}$ pombeiro@ist.utl.pt
}

Received November 2, 2012; revised December 6, 2012; accepted December 16, 2012

\begin{abstract}
The styrene-maleic anhydride copolymer was chemically modified, in the presence of formaldehyde, with 4-amino2-hydroxybenzoic acid or 4-aminobenzoic acid giving sorbents $S_{1}$ and $S_{2}$, respectively. The specific sorption behaviour of $S_{1}$ and $S_{2}$ towards germanium(IV) was examined and optimized, the preconcentrated germanium(IV) after desorption being spectrophotometrically quantified with bis(2,3,4-trihydroxyphenylazo)benzidine in the presence of hexamethylenetetramine, phenanthroline and 2,2'-bipyridine. The dynamic sorption capacity and detection limits $(3 \sigma, \mathrm{n}=17)$ of germanium were found to be 152.2 and $127.1 \mathrm{mg} \cdot \mathrm{g}^{-1}$, and 0.9 and $1.1 \mathrm{ng} \cdot \mathrm{mL}^{-1}$, for $\mathrm{S}_{1}$ and $\mathrm{S}_{2}$, accordingly. The application of $S_{1}$ and $S_{2}$ was demonstrated for the selective preconcentration/determination of germanium in seawater and water obtained after oil pumping.
\end{abstract}

Keywords: Germanium(IV); Preconcentration; Sorption; Spectrophotometric Determination

\section{Introduction}

Germanium is an element which is widely used in, e.g., semiconductor production or as a catalyst in production of plastics [1]. It is rather rare and is found in nature dispersed in ore deposits or being dissolved in trace quanties, mainly as soluble germanate anions and methylgermanium species $[2,3]$. The concentration of germanium and its easy determination on the trace and ultra-trace levels is of importance and has been pursued for many years $[1,4]$.

Preconcentration (also called enrichment) is a generic term for various processes employed to increase the amount of a desired element to be suitable for further processing, e.g., its determination. Preconcentration improves the analytical detection limit, increases the sensitivity by several orders of magnitude, enhances the accuracy of the results and facilitates calibration. Some preconcentration techniques, e.g., sorption [5-10], liquidliquid extraction [11-15], coprecipitation [16,17], and cloud point method [18], have been employed in combi-

${ }^{*}$ Corresponding authors. nation with spectrophotometric and spectroscopic detection methods [19-31] for the determination of germanium (Table 1). The preconcentration of germanium by sorption offers several advantages over other methods of concentration (e.g., liquid-liquid extraction), such as experimental convenience, low cost and usage of less toxic materials. To date, there are a few works related to the preconcentration of germanium on a solid substrate, for instance on Kelex-100 [29], nanometer sized $\mathrm{TiO}_{2} / \mathrm{SiO}_{2}$ [3], $\mathrm{TiO}_{2}[2,19]$, active carbon [32], cellulose [10], chitosan chelating resin [5,9], Sephadex gel [6], anionic resin (IRA-900) [31], goethite [33] and mercaptomodified silica gel [7]. However, most of the described sorbents have one or more of the following disadvantages: relatively low selectivity $[2,19,27]$, low sorption capacity [32], low rate of sorption [5,32,33] or high cost of sorbent $[2,3,30]$. Therefore, the introduction of a new inexpensive sorbent with better analytical parameters for at least some of the above mentioned points constitutes an important task.

The styrene-maleic anhydride (SMA) copolymer possesses the anhydride moieties and thus is handy for further modification [34]. It was reported that nucleophilic 
Table 1. Survey of spectrometric methods applied for the determination of germanium.

\begin{tabular}{|c|c|c|c|c|}
\hline Spectrophotometric reagent & $\begin{array}{l}\text { Limit of detection } \\
\text { (Beer's law) }\end{array}$ & Selectivity & Analyzed sample & Ref. \\
\hline Phenylfluorone and zephiramine ${ }^{a}$ & $47.5 \mu \mathrm{g} \cdot \mathrm{mL}^{-1}\left(0-0.10 \mu \mathrm{g} \cdot \mathrm{mL}^{-1}\right)$ & $\begin{array}{l}\mathrm{Sn}(\mathrm{II}, \mathrm{IV}), \mathrm{Sb}(\mathrm{III}) \\
\mathrm{Ta}(\mathrm{V}), \mathrm{Nb}(\mathrm{V}), \mathrm{W}(\mathrm{VI}) \\
\mathrm{Mo}(\mathrm{VI})\end{array}$ & $\begin{array}{l}\text { Hot spring water } \\
\text { and groundwater }\end{array}$ & {$[8]$} \\
\hline Phenylfluorone $^{\mathrm{a}}$ & & $\begin{array}{l}\mathrm{Sb}(\mathrm{III}), \mathrm{Sb}(\mathrm{V}), \mathrm{Sn}(\mathrm{II}) \\
\mathrm{Sn}(\mathrm{IV}), \mathrm{Mo}(\mathrm{V} 1) \\
\mathrm{Ti}(1 \mathrm{~V})\end{array}$ & Lignite ashes & {$[11]$} \\
\hline Phenylfluorone $^{\mathrm{a}}$ & $0.05 \mathrm{ppm},(0.1-0.6 \mathrm{ppm})$ & $\begin{array}{l}\mathrm{In}(\mathrm{III}), \mathrm{Fe}(\mathrm{II}), \mathrm{Te}(\mathrm{IV}) \\
\mathrm{Tl}(\mathrm{I}), \mathrm{Sn}(\mathrm{IV})\end{array}$ & & {$[20]$} \\
\hline $\begin{array}{l}\text { Catechol violet and cetyltrimethylanunoniuni } \\
\text { bromide }^{\text {a }}\end{array}$ & $(0.1-1.0 \mathrm{ppm})$ & $\begin{array}{l}\mathrm{Sn}(\mathrm{IV}), \mathrm{Fe}(\mathrm{III}), \mathrm{Bi}(\mathrm{III}) \\
\mathrm{Cr}(\mathrm{VI}), \mathrm{Mo}(\mathrm{VI}), \mathrm{V}(\mathrm{V}) \\
\mathrm{Sb}(\mathrm{III})\end{array}$ & & {$[21]$} \\
\hline o-Chlorophenylfluorone ${ }^{a}$ & $\begin{array}{c}0.01 \mathrm{mg} \cdot \mathrm{L}^{-1} \\
\left(0-1.2 \mathrm{mg} \cdot \mathrm{mL}^{-1}\right)\end{array}$ & $\begin{array}{l}\mathrm{La}(\mathrm{III}), \mathrm{Au}(\mathrm{III}), \mathrm{Ni}(\mathrm{II}), \\
\mathrm{Co}(\mathrm{II}), \mathrm{Sn}(\mathrm{II}), \mathrm{Fe}(\mathrm{II}), \\
\mathrm{Ag}(\mathrm{I}), \mathrm{Pt}(\mathrm{IV}), \mathrm{Cr}(\mathrm{III}), \\
\mathrm{Zn}(\mathrm{II}), \mathrm{Mn}(\mathrm{II}), \mathrm{W}(\mathrm{III}), \\
\mathrm{Al}(\mathrm{III}), \mathrm{V}(\mathrm{V}), \mathrm{Ti}(\mathrm{IV}), \\
\mathrm{In}(\mathrm{III}), \mathrm{Mo}(\mathrm{IV}), \\
\mathrm{Zr}(\mathrm{IV}), \mathrm{Sb}(\mathrm{III})\end{array}$ & Water & {$[23]$} \\
\hline $\begin{array}{l}\text { 9-(o-Chlorophenyl)-2,6,7-trihydroxyxanthen-3-one } \\
\text { in the presence of cetyltrimethylammonium } \\
\text { bromide }^{\text {a }}\end{array}$ & $\left(0-0.20 \mathrm{~g} \cdot \mathrm{mL}^{-1}\right)$ & $\begin{array}{l}\mathrm{Ba}(\mathrm{II}), \mathrm{Pb}(\mathrm{II}), \mathrm{Ga}(\mathrm{III}) \\
\mathrm{Sb}(\mathrm{III}), \mathrm{V}(\mathrm{V}), \mathrm{Cr}(\mathrm{VI}) \\
\text { W(VI), Mo(VI) }\end{array}$ & Minerals and Ores & {$[26]$} \\
\hline \multicolumn{5}{|l|}{$\begin{array}{l}\text { Preconcentration/separation procedure } \\
\text { (spectrophotometric reagent) }\end{array}$} \\
\hline Pyrogallol $^{\text {b }}$ & $1.2 \times 10^{-9} \mathrm{M}\left(0-1 \times 10^{-8} \mathrm{M}\right)$ & As(III), Sn(IV) & Ore & {$[29]$} \\
\hline Nano-sized $\mathrm{TiO}_{2}{ }^{\mathrm{c}}$ & $43 \mathrm{ng} \mathrm{L}^{-1}$ & $\mathrm{Sr}(\mathrm{II}), \mathrm{Zn}(\mathrm{II}), \mathrm{PO}_{4}{ }^{3-}, \mathrm{F}^{-}$ & Water & {$[2]$} \\
\hline $\begin{array}{l}\mathrm{Nano}^{-\mathrm{TiO}_{2}} \text { (salicyl fluorone in the presence of } \\
\text { cetyltrimethylammonium bromide) }\end{array}$ & $\begin{array}{c}7.2 \mathrm{ng} \cdot \mathrm{mL}^{-1} \\
\left(0-0.24 \mu \mathrm{g} \cdot \mathrm{mL}^{-1}\right)\end{array}$ & $\begin{array}{l}\mathrm{Si}(\mathrm{IV}), \mathrm{Sn}(\mathrm{IV}), \mathrm{Al}(\mathrm{III}) \\
\mathrm{Fe}(\mathrm{III})\end{array}$ & $\begin{array}{l}\text { Water and certified } \\
\text { reference material } \\
(\mathrm{GBW} 07311)\end{array}$ & {$[3]$} \\
\hline Mercapto-modified silica gel $^{\mathrm{d}}$ & $0.813 \mathrm{ng} \cdot \mathrm{L}^{-1}\left(0.01-0.20 \mu \mathrm{g} \cdot \mathrm{mL}^{-1}\right)$ & $\mathrm{Co}(\mathrm{II}), \mathrm{Cu}(\mathrm{II}), \mathrm{Ni}(\mathrm{II})$ & & {$[7]$} \\
\hline $\begin{array}{l}\text { Preconcentration on an organic solvent-soluble } \\
\text { membrane and determination with } \\
o \text {-nitrophenylfiuorone in presence of sodium } \\
\text { dodecyl sulfate }^{\mathrm{a}}\end{array}$ & $\begin{array}{c}0.4 \mu \mathrm{g} \cdot \mathrm{L}^{-1} \\
\left(0.02-0.36 \mu \mathrm{g} \cdot \mathrm{mL}^{-1}\right)\end{array}$ & $\mathrm{Pb}(\mathrm{II}), \mathrm{Mo}(\mathrm{VI})$ & $\begin{array}{l}\text { Chinese herb, } \\
\text { natural water, } \\
\text { drinking water, } \\
\text { urine samples }\end{array}$ & {$[14]$} \\
\hline $\begin{array}{l}\text { Coprecipitation of germanium in the presence of } \\
\mathrm{Mg}^{2+}, \mathrm{Ga}^{3+}, \mathrm{Ca}^{2+} \text { and } \mathrm{HCO}^{3-\mathrm{e}}\end{array}$ & $0.6 \mathrm{pg} \cdot \mathrm{mL}^{-1}$ & & $\begin{array}{l}\text { Sea-water, surface } \\
\text { water and } \\
\text { ground-water }\end{array}$ & {$[16]$} \\
\hline Nickel hydroxide ${ }^{f}$ & $0.11 \mu \mathrm{gL}^{-1}$ & $\begin{array}{l}\mathrm{Pb}, \mathrm{Fe}, \mathrm{Co}, \mathrm{Cd}, \mathrm{Cu} \\
\mathrm{Ag}, \mathrm{Al}\end{array}$ & $\begin{array}{l}\text { Standard } \\
\text { reference, } \\
\text { GBW07302, } \\
\text { GBW07308 }\end{array}$ & {$[17]$} \\
\hline Cloud point methodology, triton $X-114^{\mathrm{d}}$ & $0.59 \mu \mathrm{gL}{ }^{-1}\left(10-30 \mu \mathrm{g} \cdot \mathrm{L}^{-1}\right)$ & As, $\mathrm{Te}, \mathrm{Sb}$ & $\begin{array}{l}\text { Tap and drinking } \\
\text { water }\end{array}$ & {$[18]$} \\
\hline $\begin{array}{l}\mathrm{TiO}_{2} \text { nanoparticles (salicyl fluorone in the } \\
\text { presence of cetyltrimethylammonium bromide) }\end{array}$ & & $\begin{array}{l}\mathrm{Cu}(\mathrm{II}), \mathrm{Ba}(\mathrm{II}), \mathrm{Cd}(\mathrm{II}), \\
\mathrm{Co}(\mathrm{II}), \mathrm{Ni}(\mathrm{II}), \mathrm{Se}(\mathrm{IV}), \\
\mathrm{Sr}(\mathrm{II}), \mathrm{Li}(\mathrm{I}), \mathrm{Si}(\mathrm{IV})\end{array}$ & & {$[19]$} \\
\hline Heteropolymolybdate $^{a}$ & & & $\begin{array}{l}\text { Almond tree ashes, } \\
\text { orange tree ashes, } \\
\text { biotite (mica-Fe } \\
\text { CPRG) and basalt } \\
\text { (BE-NCRPG) }\end{array}$ & {$[22]$} \\
\hline $\begin{array}{l}\text { Precipitation with } \mathrm{Fe}(\mathrm{OH})_{3} \text { and determination with } \\
\text { trimethoxylphenylfluorone }^{\mathrm{a}}\end{array}$ & $0.21 \mathrm{ng} \cdot \mathrm{ml}^{-1}\left(0-0.24 \mu \mathrm{g} \cdot \mathrm{mL}^{-1}\right)$ & $\begin{array}{l}\mathrm{Sr}(\mathrm{II}), \mathrm{Pb}(\mathrm{II}), \mathrm{Zr}(\mathrm{IV}) \\
\mathrm{Ti}(\mathrm{IV}), \mathrm{Mo}(\mathrm{VI})\end{array}$ & Foods & {$[24]$} \\
\hline $\begin{array}{l}\text { (Methybenzeneazosalicylfluorone) using } \\
\text { ultrasound-assisted leaching }^{\mathrm{a}}\end{array}$ & $\begin{array}{c}2.75 \mathrm{ng} \cdot \mathrm{L}^{-1} \\
\left(0-0.72 \mu \mathrm{g} \cdot \mathrm{mL}^{-1}\right)\end{array}$ & $\begin{array}{l}\mathrm{Cr}(\mathrm{III}), \mathrm{Hg}(\mathrm{II}), \mathrm{Ti}(\mathrm{IV}), \\
\mathrm{U}(\mathrm{VI}), \mathrm{As}(\mathrm{III}), \mathrm{Bi}(\mathrm{III}), \\
\mathrm{Se}(\mathrm{VI}), \mathrm{Te}(\mathrm{VI}), \mathrm{Be}(\mathrm{II}), \\
\mathrm{Pt}(\mathrm{IV}), \mathrm{Pt}(\mathrm{II}), \mathrm{Pd}(\mathrm{II}), \\
\mathrm{Ru}(\mathrm{IV}), \mathrm{Ir}(\mathrm{III}), \mathrm{Os}(\mathrm{VI}), \\
\mathrm{Ag}(\mathrm{I}), \mathrm{Au}(\mathrm{III})\end{array}$ & $\begin{array}{l}\text { Certified } \\
\text { reference } \\
\text { materials } \\
\text { (GBW07401 and } \\
\text { GBW07402) }\end{array}$ & {$[25]$} \\
\hline
\end{tabular}




\begin{tabular}{|c|c|c|c|c|}
\hline $\begin{array}{l}\text { Kelex-100, } \\
\text { [7-(4-ethyl-1-methyloctyl)-8-hydroxyquinoline] } \\
\text { functional sol gel }^{\mathrm{b}}\end{array}$ & & $\begin{array}{l}\mathrm{As}(\mathrm{II}), \mathrm{Sb}(\mathrm{III}), \mathrm{Zn}(\mathrm{II}) \\
\mathrm{Ni}(\mathrm{II})\end{array}$ & Water & {$[27]$} \\
\hline Chitosan functionalized with di-2-propanolamine ${ }^{\mathrm{g}}$ & $0.002 \mu \mathrm{g} \mathrm{L}{ }^{-1}\left(0-50 \mu \mathrm{g} \cdot \mathrm{L}^{-1}\right)$ & & $\begin{array}{l}\text { Tap water, river } \\
\text { water and } \\
\text { seawater }\end{array}$ & [28] \\
\hline $\begin{array}{l}\text { The separation was performed by an isocratic } \\
\text { elution }\end{array}$ & $\left(0.05-5.00 \mu \mathrm{g} \cdot \mathrm{mL}^{-1}\right)$ & & Tonic oral liquids & {$[30]$} \\
\hline Anionic resin (IRA-900), catechol ${ }^{\mathrm{i}}$ & & & Fly ash & {$[31]$} \\
\hline $\begin{array}{l}\text { Modified copolymer styrene-maleic anhydride, } \\
\text { (bis(2,3,4-trihydroxyphenylazo) benzidine in the } \\
\text { presence of heterocyclic amines) }\end{array}$ & $\begin{array}{c}0.9 \mathrm{ng} \cdot \mathrm{mL}^{-1} \\
\left(1.2-18.2 \mathrm{ng} \cdot \mathrm{mL}^{-1}\right)\end{array}$ & $\mathrm{Cu}(\mathrm{II}), \mathrm{Fe}(\mathrm{III})$ & $\begin{array}{l}\text { Seawater and } \\
\text { water obtained } \\
\text { after oil pumping }\end{array}$ & $\begin{array}{l}\text { This } \\
\text { work }\end{array}$ \\
\hline
\end{tabular}

Detection technique: ${ }^{a}$ spectrophotometery; ${ }^{b}$ adsorptive stripping voltammetric; ${ }^{c}$ graphite furnace atomic absorption spectrometry; ${ }^{\mathrm{d}}$ hydride generation flame

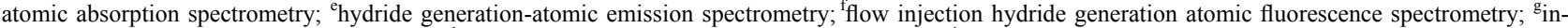
ductively coupled plasma mass spectrometry; ${ }^{\mathrm{h}}$ high-performance ion-exclusion chromatography; ${ }^{\mathrm{i}}$ atomic absorption spectrometry.

amino-or hydroxyl-containing compounds were involved in the modification of the SMA copolymer by a ringopening reaction [35]; the SMA was also modified by various alkali and used as a pigment dispersant [36,37]. However, to the best of our knowledge, SMA has not been modified with compounds containing chelating groups in the presence of formaldehyde. In particular, modification of the SMA copolymer with 4-amino-2hydroxybenzoic acid (giving polymer $\mathrm{S}_{1}$ ) and 4-aminobenzoic acid (giving polymer $S_{2}$ ) in the presence of formaldehyde in water (Scheme 1) has not been performed before this work.

From another perspective, different analytical reagents have already been used for the spectrophotometric determination of germanium(IV) (see Table 1), but, the analytical parameters for most of them are rather moderate. In fact, none of the described reagents has good integrate analytical parameters (low detection limits, large Beer's law interval and selectivity, low cost). In view of that, we decided to introduce a new effective analytical reagent-bis(2,3,4-trihydroxyphenylazo)benzidine $\left(\mathrm{H}_{6} \mathrm{~L}\right.$, Scheme 2) for easy and straightforward determination of germanium(IV).

Thus, the aim of this work is to develop a new routine method for the effective preconcentration of germanium (IV) combined with its easy spectrophotometric determination.

\section{Experimental}

\subsection{Materials and Instrumentation}

All the chemicals were obtained from commercial sources (Aldrich) and used as received. Infrared spectra $\left(4000-400 \mathrm{~cm}^{-1}\right)$ were recorded on a BIO-RAD FTS $3000 \mathrm{MX}$ instrument in $\mathrm{KBr}$ pellets. To create the necessary $\mathrm{pH}$ values, a commercial volumetric concentrate (fixanal) of $\mathrm{HCl}(\mathrm{pH} 1-2)$ and an ammonium acetate buffer solution ( $\mathrm{pH} 3$ - 11) were used. The acidity of the

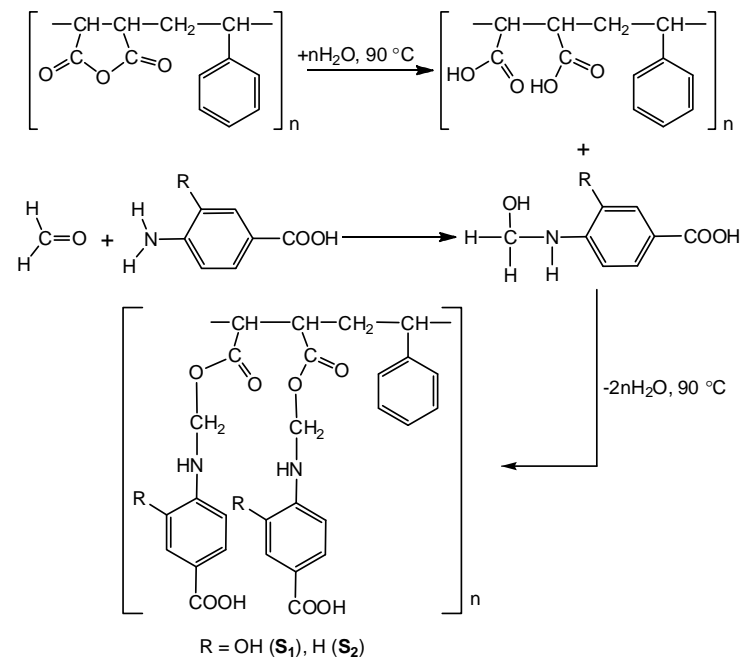

Scheme 1. Synthesis of the sorbents.

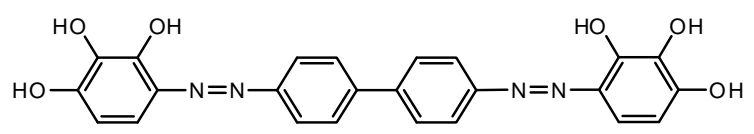

Scheme 2. Bis(2,3,4-trihydroxyphenylazo)benzidine $\left(\mathrm{H}_{6} \mathrm{~L}\right)$.

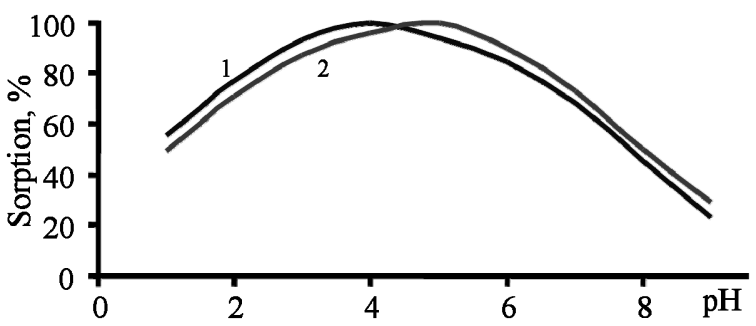

Figure 1. Effect of pH on the Ge(IV) sorption by the chelating sorbents $S_{1}$ (1) and $S_{2}(2)$ in the static mode. Ge(IV) concentration: $100 \mathrm{mg} \cdot \mathrm{L}^{-1}$; sample volume: $25 \mathrm{~mL} ; 50 \mathrm{mg}$ sorbent.

solutions was measured using an I-130 potentiometer with an ESL-43-07 glass electrode adjusted by standard buffer solutions and an EVL-1M3.1 silver-silver chloride 
reference electrode. The absorbance of the solutions was measured on a Lambda 40 spectrophotometer (Perkin Elmer) in $1 \mathrm{~cm}$ quartz cells. $1.00 \times 10^{-3} \mathrm{M}$ ethanol solutions of $\mathrm{H}_{6} \mathrm{~L}$, hexamethylenetetramine (HA), phenanthroline (PA) and 2,2'-bipyridine (BP) were used. A starting $1.00 \times 10^{-1} \mathrm{M}$ solution of germanium(IV) was prepared by dissolving metallic germanium $(99.99 \%)$ as described [38] and the concentration of Ge(IV) was determined by atomic absorption spectroscopy [39]. The stock solutions of the various metal ions $\left(\mathrm{mg} \cdot \mathrm{L}^{-1}\right)$ were prepared with their nitrate or chloride salts $(\geq 99.99 \%)$ and used to investigate the possible effects of interfering ions. Doubly distilled water was used throughout the experiments. In desorption of germanium, $0.2-3.0 \mathrm{M}$ acid solutions (prepared from $\mathrm{H}_{2} \mathrm{SO}_{4} 98 \% \mathrm{w} / \mathrm{w}, \mathrm{HClO}_{4}$ $60 \% \mathrm{w} / \mathrm{w}, \mathrm{HCl} 33 \% \mathrm{w} / \mathrm{w}, \mathrm{HNO}_{3} 65 \% \mathrm{w} / \mathrm{w}$ ) were used. Glass mini-column $(5 \mathrm{~mm}$ i.d. $\times 50 \mathrm{~mm})$ was used for packing the sorbent in dynamic sorption study.

\subsection{Syntheses of SMA}

Copolymerization of maleic anhydride with styrene (1:1 ratio) was performed as described [40-42]: $250 \mathrm{~mL}$ round bottom flask was loaded with $70 \mathrm{~mL}$ benzene as a solvent and $15.6 \mathrm{~g}$ ( 0.149 mole) of styrene, $14.7 \mathrm{~g}$ (0.149 mole) of maleic anhydride and azobisisobutyronitrile as an initiator $(1.6 \mathrm{~mole} \%)$. The mixture was stirred for $14 \mathrm{~h}$ at $70^{\circ} \mathrm{C}$ under nitrogen atmosphere. After reaction, the reaction mixture was cooled to room temperature and poured into a large volume $(200 \mathrm{~mL})$ of diethyl ether; the polymer product (SMA) precipitated as a white powder, which then was filtered off and dried overnight under vacuum at $50^{\circ} \mathrm{C}$ to constant weight (yield $95 \%$ ).

Then the SMA polymer was chemically modified with aminobenzoic acids in the presence of formaldehyde: a part of the synthesized SMA $(4 \mathrm{~g})$, formaldehyde $(5 \mathrm{~mL}$, $38 \%$ water solution) and 4-amino-2-hydroxybenzoic acid ( $2 \mathrm{~g}$, for the synthesis of $\mathrm{S}_{1}$ ), or 4-aminobenzoic acid ( $2 \mathrm{~g}$, for the synthesis of $\mathrm{S}_{2}$ ) were mixed in $60 \mathrm{~mL}$ water at $90^{\circ} \mathrm{C}$ and stirred for $3 \mathrm{~h}$. The chemically modified product was filtered on a filter paper and washed 2 times with small portions $(5 \mathrm{~mL})$ of water and dried at $50^{\circ} \mathrm{C}$ in oven.

\subsection{Construction of Calibration Curves for Spectrophotometric Determination}

To determine the limits of detection and correspondence to the Beer's law, portions of $0.02-1.40 \mathrm{~mL}$ of the 1.00 $\times 10^{-3} \mathrm{M}$ reference germanium(IV) solution were placed into eight $25.00 \mathrm{~mL}$ calibrated flasks. Then $2.00 \mathrm{~mL}$ of $1.00 \times 10^{-3} \mathrm{M}$ ethanol solutions of $\mathrm{H}_{6} \mathrm{~L}$ and $2.00 \mathrm{~mL}$ of $1.00 \times 10^{-3} \mathrm{M}$ ethanol solutions of HA (or PA, BP) were added, and the mixtures were diluted up to the mark with $0.01 \mathrm{M} \mathrm{HCl}$. The absorbance of the solutions was measured $\left(\lambda_{\max } \mathrm{nm}, l=1 \mathrm{~cm}\right)$ against the reference solution giving the corresponding calibration curve.

\subsection{Effect of pH on the Sorption at Static Conditions}

The static sorption experiments were carried out using a series of $25 \mathrm{~mL}$ Erlenmeyer flasks containing $50 \mathrm{mg}$ sorbents and $100 \mathrm{mg} \cdot \mathrm{L}^{-1}$ germanium solution at different $\mathrm{pH}$ and stirred for $1 \mathrm{~h}$. After $1 \mathrm{~h}$ the concentration of Ge(IV) in solution was measured by a spectrophotometric method: an aliquot $(1 \mathrm{~mL})$ was placed into a 25.00 $\mathrm{mL}$ volumetric flask, then $1.00 \mathrm{~mL}$ of $1.00 \times 10^{-3} \mathrm{M} \mathrm{H}_{6} \mathrm{~L}$ and $1.00 \mathrm{~mL}$ of $1.00 \times 10^{-3} \mathrm{M}$ BP solutions were added and the mixture was diluted to mark with $0.01 \mathrm{M} \mathrm{HCl}$. The absorbance of the solution was measured at $477 \mathrm{~nm}$ against the blank experiment. The concentration of germanium was found using the calibration curve. The sorption percentage (sorption, \%) was calculated based on the following equation [43]:

$$
\text { Sorption, } \%=\frac{\left(C_{\mathrm{i}}=C_{\mathrm{e}}\right)}{C_{\mathrm{i}}} \times 100
$$

where $C_{\mathrm{i}}$ is the initial concentration $\left(\mathrm{mg} \cdot \mathrm{L}^{-1}\right), C_{\mathrm{e}}$ the equilibrium metal ion concentration $\left(\mathrm{mg} \cdot \mathrm{L}^{-1}\right)$ in solution.

\subsection{Optimization of Flow Rates and Selection of Eluent Solution}

A micro-column $(5 \mathrm{~mm}$ i.d. $\times 50 \mathrm{~mm}$ in lenght $)$ was filled with a total of $50 \mathrm{mg}$ of $\mathrm{S}_{1}$ or $\mathrm{S}_{2}$, and tapped with glass wool. A solution containing $25 \mathrm{~mL}$ of $200 \mathrm{mg} \cdot \mathrm{L}^{-1}$ $\mathrm{Ge}(\mathrm{IV})$ with $\mathrm{pH}$ value adjusted to 4 (5 in the case of $\mathrm{S}_{2}$ ) with ammonium acetate buffer solution was passed through the micro-column at a flow rate of $0.1-3.0 \mathrm{~mL}$ $\min ^{-1}$.

To select an appropriate eluent, $0.2-3.0 \mathrm{M}$ acid solutions (prepared from $\mathrm{H}_{2} \mathrm{SO}_{4} 98 \% \mathrm{w} / \mathrm{w}, \mathrm{HClO}_{4} 60 \% \mathrm{w} / \mathrm{w}$, $\mathrm{HCl} 33 \% \mathrm{w} / \mathrm{w}, \mathrm{HNO}_{3} 65 \% \mathrm{w} / \mathrm{w}$ ) were passed through the column with $0.1-3.0 \mathrm{~mL} \cdot \mathrm{min}^{-1}$ flow rate.

\subsection{Dynamic Sorption Capacity}

Dynamic sorption capacity of sorbents towards germanium was examined by passing $25 \mathrm{~mL}, 400 \mathrm{mg} \cdot \mathrm{L}^{-1}$ $\mathrm{Ge}(\mathrm{IV})$ solution through micro-column containing $50 \mathrm{mg}$ sorbent with $1.4 \mathrm{~mL} \cdot \mathrm{min}^{-1}$ flow rate. Each $25 \mathrm{~mL}$ of the eluent was collected for the determination of Ge(IV) concentration until Ge(IV) concentration equates the initial concentration. After the column, the concentration of Ge(IV) was measured by spectrophotometric method. The sorption capacity of sorbents was calculated by the following equation [43]:

$$
q=\frac{V \times\left(C_{i}-C_{f}\right)}{m}
$$


where $q$ is the sorption capacity of sorbents $\left(\mathrm{mg} \cdot \mathrm{g}^{-1}\right) ; V$ is the volume of the solution in $\mathrm{L} ; C_{\mathrm{i}}$ is the initial concentration $\left(\mathrm{mg} \cdot \mathrm{L}^{-1}\right), C_{\mathrm{f}}$ is the final concentration of $\mathrm{Ge}(\mathrm{IV})$ after passing through column $\left(\mathrm{mg} \cdot \mathrm{L}^{-1}\right), m$ is the mass of added sorbent in $\mathrm{g}$.

\subsection{Construction of Calibration Curves for Sorption-Spectrophotometric Determination}

The calibration graphs were constructed under selected conditions $(50 \mathrm{mg}$ sorbent, $\mathrm{pH} 4$ and 5 , flow rate of sample 1.4 and $1.7 \mathrm{~mL} \mathrm{~min}^{-1}$ and flow rate of eluent 1.0 and $1.3 \mathrm{~mL} \mathrm{~min}^{-1}$ for $\mathrm{S}_{1}$ and $\mathrm{S}_{2}$, respectively). To determine the concentration of $\mathrm{Ge}(\mathrm{IV})$ with $\mathrm{H}_{6} \mathrm{~L}$ in the presence of $\mathrm{BP}, 1.00-12.00 \mathrm{~mL}$ portions of $6.31 \times 10^{-7} \mathrm{M}(7.50 \times$ $10^{-7} \mathrm{M}$ when $\mathrm{S}_{2}$ used as sorbent) reference Ge(IV) solution were passed through the micro-column and the retained $\mathrm{Ge}(\mathrm{IV})$ was repeatedly eluated by $1 \mathrm{~mL}$ of $1 \mathrm{M}$ $\mathrm{HCl}$ into each of eight $25.00 \mathrm{~mL}$ calibrated flasks. Then $1.00 \mathrm{~mL}$ of $1.00 \times 10^{-3} \mathrm{M}$ solution of $\mathrm{H}_{6} \mathrm{~L}$ and $1.00 \mathrm{~mL}$ of $1.00 \times 10^{-3} \mathrm{M}$ solution of BP were added to each flask, and the mixtures were diluted up to the mark with bidistilled water. Absorbance of the solutions was measured $(\lambda=477 \mathrm{~nm}, l=1 \mathrm{~cm})$ against the reference; the Beer's law was obeyed in the range of $1.2-18.2$ and $1.4-21.6$ $\mathrm{ng} \cdot \mathrm{mL}^{-1}$ for $\mathrm{S}_{1}$ and $\mathrm{S}_{2}$, respectively. The limit of detection, as determined from the intersection of the two extrapolated segments of the calibration graph, was 0.9 and $1.1 \mathrm{ng} \cdot \mathrm{mL}^{-1}(3 \sigma, \mathrm{n}=17)$ for $\mathrm{S}_{1}$ and $\mathrm{S}_{2}$, respectively.

\subsection{Effect of the Matrix Components on Sorption}

The effect of foreign ions on the determination of germanium was examined as follows: $25 \mathrm{~mL}$ portions of solutions with $10 \mathrm{mg} \cdot \mathrm{L}^{-1} \mathrm{Ge}(\mathrm{IV})$ and foreign ions in the range concentration of $25-900 \mathrm{mg} \cdot \mathrm{L}^{-1}$ were prepared. An individual solution of germanium(IV) $(25 \mathrm{~mL}$ with $10 \mathrm{mg} \cdot \mathrm{L}^{-1}$ ) without addition of foreign ions was used as a control. All the solutions were passed through the micro-column packed with a sorbent (50 $\mathrm{mg} \mathrm{S}_{1}$ or $\mathrm{S}_{2}$, flow rate 1.4 and $1.7 \mathrm{~mL} \cdot \mathrm{min}^{-1}$ for $\mathrm{S}_{1}$ and $\mathrm{S}_{2}$, respectively). $\mathrm{Ge}(\mathrm{IV})$ was quantitatively eluted by $1.0 \mathrm{~mL}$ of $1 \mathrm{M} \mathrm{HCl}$ solution (1.0 and $1.3 \mathrm{~mL} \mathrm{~min}^{-1}$ for $\mathrm{S}_{1}$ and $\mathrm{S}_{2}$, respectively) and determined spectrophotometrically.

\subsection{Natural Samples Preparation and Analyses}

\subsubsection{Seawater Sample}

To $1000 \mathrm{~mL}$ of water taken from Caspian Sea near Turkan village (Azerbaijan) was added ammonium acetate buffer to reach $\mathrm{pH} 4$ (or 5 in the case of $\mathrm{S}_{2}$ ) and passed through the column with $50 \mathrm{mg}$ of sorbent $S_{1}$ and with flow rate of $1.4 \mathrm{~mL} \cdot \mathrm{min}^{-1}$. The sorbed germanium ions were eluted by $1 \mathrm{~mL}$ of $1 \mathrm{M} \mathrm{HCl}$ to $25 \mathrm{~mL}$ flask at a flow rate of $1.0 \mathrm{~mL} \mathrm{~min}^{-1}$; then $1.00 \mathrm{~mL}$ of $1.00 \times 10^{-3} \mathrm{M} \mathrm{H}_{6} \mathrm{~L}$, $1.00 \mathrm{~mL}$ of $1.00 \times 10^{-3} \mathrm{M} \mathrm{BP}, 0.50 \mathrm{~mL}$ of $0.01 \mathrm{M}$ oxalic acid were added, and the mixtures were diluted up to the mark with bidistilled water. The absorbance of the solutions was measured $(\lambda=477 \mathrm{~nm}, l=1 \mathrm{~cm})$ against the reference solution.

\subsubsection{Water Obtained after Oil Pumping}

To $1000 \mathrm{~mL}$ of the filtered water obtained in oil pumping (Dubendi, Azerbaijan), an ammonium acetate buffer was added to adjust $\mathrm{pH}$ to 4 (or 5 in the case of $\mathrm{S}_{2}$ ) and then the solution was passed through the column with 1.4 $\mathrm{mL} \cdot \mathrm{min}^{-1}$ flow rate $\left(\mathrm{S}_{1}\right)$. The sorbed $\mathrm{Ge}(\mathrm{IV})$ ions were

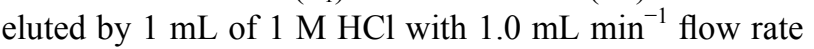
and their concentration in the eluate was determined by spectrophotometry and atomic absorption spectrophotometry.

\section{Results and Discussion}

\subsection{Spectrophotometric Determination}

In this work we introduce a new method of spectrophotometric determination of Ge(IV) with bis(2,3,4-trihydroxyphenylazo)benzidine $\left(\mathrm{H}_{6} \mathrm{~L}\right.$, Scheme 2) as a spectrophotometric agent. The synthesis and characterization of $\mathrm{H}_{6} \mathrm{~L}$ were reported earlier by some of us [44], and hence will not be discussed. An investigation of the $\mathrm{Ge}(\mathrm{IV})-\mathrm{H}_{6} \mathrm{~L}$ system in a wide range of $\mathrm{pH}$ values showed that $\mathrm{H}_{6} \mathrm{~L}$ reacts with germanium(IV) ions in a weakly acidic medium to form an orange soluble compound; the most intensive coloration develops at $\mathrm{pH} 4.0$ (Table 2). It should be noted that, when $\mathrm{pH}$ is below $2.0, \mathrm{Ge}(\mathrm{IV})$ exists as $\mathrm{Ge}^{4+}$, while within the $\mathrm{pH}$ range of $3.0-9.1$, the aqueous $\mathrm{Ge}^{4+}$ species hydrolyze to the neutral $\mathrm{Ge}(\mathrm{OH})_{4}$. When $\mathrm{pH}$ ranges from 9.1 to 12.1 , the hydrolysis proceeds further leading to the negatively charged $\mathrm{GeO}(\mathrm{OH})_{3}{ }^{-}$; and when $\mathrm{pH}$ is above 12.0 , the primary species are $\mathrm{GeO}_{3}{ }^{2-}$ [3]. To simplify the interpretation, it is necessary to eliminate hydroxo-oxo complex formation, i.e., to find a way to determine $\mathrm{Ge}(\mathrm{IV})$ at $\mathrm{pH} \leq 2$. It was found by us that at $\mathrm{pH} 2$ the absorbance of solutions significantly increases when hexamethylenetetramine (HA), phenanthroline (PA) and 2,2'-bipyridine (BP) were added (Table 2).

To determine the stoichiometry of the components in $\mathrm{Ge}(\mathrm{IV})-\mathrm{H}_{6} \mathrm{~L}-\mathrm{HA}, \mathrm{Ge}(\mathrm{IV})-\mathrm{H}_{6} \mathrm{~L}-\mathrm{PA}$ and $\mathrm{Ge}(\mathrm{IV})-\mathrm{H}_{6} \mathrm{~L}-\mathrm{BP}$ systems, we used the curve-crossing method [45]. The Astakhov method [45] showed that in the presence and absence of HA, PA, or BP the slope of dependence of $\mathrm{pH}$ from $\lg \left[\Delta A /\left(\Delta A_{\text {lim }}-\Delta A\right)\right]$ equals 4 at $\mathrm{pH} 1-2$; hence, the molar ratios of the components in associates Ge(IV): $\mathrm{H}_{6} \mathrm{~L}: \mathrm{HA}$ (or PA, BP) can be 2:2:2, respectively. The obedience to the Beer's law is determined for each system (Section 2.2, Table 2). The selectivity of reaction 
Table 2. Characteristics of the complexes.

\begin{tabular}{lcccc}
\hline \multicolumn{1}{c}{ System } & $\lambda_{\max }, \mathrm{nm} \Delta \lambda, \mathrm{nm} \begin{array}{c}\varepsilon_{\max } \times 10^{-4}, \\
\mathrm{~L} \cdot \mathrm{mol}^{-1} \cdot \mathrm{cm}^{-1}\end{array}$ & $\begin{array}{c}\text { Beer's law is } \\
\text { obeyed, } \mathrm{mg} \cdot \mathrm{L}^{-1}\end{array}$ \\
\hline Ge(IV)-H $\mathrm{H}_{6} \mathrm{~L}$ & 458 & 73 & $4.50 \pm 0.01$ & $0.35-3.46$ \\
Ge(IV)- $\mathrm{H}_{6} \mathrm{~L}-\mathrm{HA}$ & 469 & 65 & $5.15 \pm 0.01$ & $0.28-2.88$ \\
Ge(IV)-H $\mathrm{H}_{6} \mathrm{~L}-\mathrm{PA}$ & 466 & 69 & $5.31 \pm 0.01$ & $0.23-2.88$ \\
Ge(IV)- $\mathrm{H}_{6} \mathrm{~L}-\mathrm{BP}$ & 477 & 71 & $5.53 \pm 0.01$ & $0.23-3.46$ \\
\hline
\end{tabular}

was studied with combination of dynamic sorption procedures.

\subsection{Preparation of Sorbents}

Upon chemical modification of SMA with aminobenzoic acids in the presence of formaldehyde (see Section 2.2.), the anhydride is hydrolyzed while the amino group couples with formaldehyde; subsequently the reaction of carboxy group with hydroxyl group of 3-hydroxy-4((hydroxymethyl)amino)benzoic acid (obtained from reaction of formaldehyde with 4-amino-2-hydroxybenzoic acid) occurs with elimination of the water molecules (Scheme 1). The IR spectrum of SMA shows two peaks at about 1850 and $1780 \mathrm{~cm}^{-1}$ corresponding to the stretching vibrations of the anhydride moiety [42]. In IR spectrum of $\mathrm{S}_{1}$ and $\mathrm{S}_{2}$ the $\mathrm{O}-\mathrm{H}, \mathrm{N}-\mathrm{H}, \mathrm{C}=\mathrm{O}$ and $\mathrm{C}-\mathrm{N}$ were observed at 3550 - 3223, 3050 - 2986, 1725 - 1654 and $1610-1523 \mathrm{~cm}^{-1}$, respectively, thus new peaks in $\mathrm{S}_{1}$ and $\mathrm{S}_{2}$ appear at $1725-1654 \mathrm{~cm}^{-1}$ confirming the ring opening. The reaction of SMA with aminobenzoic acids most probably occurs according to the mechanism reported in [42].

\subsection{Optimization of the Sorption Procedure}

\subsubsection{Effect of $\mathrm{pH}$}

The sorption behavior of $\mathrm{S}_{1}$ and $\mathrm{S}_{2}$ was examined at the $\mathrm{pH}$ range from 1 to 10 (Figure 1). In solutions, the concentration of Ge(IV) is checked by the spectrophotometric method (after $1 \mathrm{~h}$ ). It was found that the modification of the aromatic part of 4-aminobenzoic acid with -OH group influences the optimal $\mathrm{pH}$ of sorption and shifts it to the acidic medium. The low sorption at $\mathrm{pH}$ less then 4 can be associated with the protonation of functional groups of the sorbent and a low degree of swelling of the polymer. At such $\mathrm{pH}$ values, Ge(IV) ions occur in a hydrated $\left[\mathrm{Ge}\left(\mathrm{OH}_{2}\right)_{\mathrm{n}}\right]^{4+}$ form [3]. The swelling capacity of the polymer sorbent grows as $\mathrm{pH}$ increases $(\mathrm{pH} 4-5)$, which favors the interaction between metal ions and coordinatively active groups of the sorbent. At higher $\mathrm{pH}$ values, the hydrolysis prevails and, as a consequence, the degree of Ge(IV) sorption is gradually reduced. Thus, all of the following experiments were carried out at $\mathrm{pH} 4$ (for $\mathrm{S} 1$ ) and $\mathrm{pH} 5$ (for S2).

\subsubsection{Optimization of Flow Rates and Selection of the Eluent Solutions}

The variation of flow rates within the $0.1-3.0 \mathrm{ml} \mathrm{min}{ }^{-1}$ interval indicated that a quantitative recovery $(>95 \%)$ of $\mathrm{Ge}(\mathrm{IV})$ was obtained at the flow rate of 1.4 and 1.7 $\mathrm{mL} \cdot \mathrm{min}^{-1}$ for $\mathrm{S}_{1}$ and $\mathrm{S}_{2}$, respectively. The recoveries of $\mathrm{Ge}(\mathrm{IV})$ decrease rapidly with increasing the flow rate from 1.4 (or 1.7) to 2.0 (or 2.5) $\mathrm{mL} \cdot \mathrm{min}^{-1}$. Higher flow rates seem to cause incomplete chelation of the cations on the sorbent. Therefore, the flow rates of 1.4 and 1.7 $\mathrm{mL} \cdot \mathrm{min}^{-1}$ were chosen for $\mathrm{S}_{1}$ and $\mathrm{S}_{2}$, respectively.

A number of acids with different concentrations (0.2 $2.0 \mathrm{M})$ were studied for the elution of Ge(IV) retained on $S_{1}$ and $S_{2}$ (Figure 2). Upon variation of the eluent solutions, it was found that the recovery of Ge(IV) is strongly depended on the eluent flow rate, the higher the flow rate of the solution, the lower the recovery. When the flow rate was controlled within the range of $1.0-1.3$ $\mathrm{mL} \cdot \mathrm{min}^{-1}$, the recoveries of $\mathrm{Ge}(\mathrm{IV})$ was over $98 \%$. In the subsequent experiments, $1 \mathrm{~mL}$ of $1 \mathrm{M} \mathrm{HCl}$ (flow rate 1.0 and $1.3 \mathrm{~mL} \cdot \mathrm{min}^{-1}$ for $\mathrm{S}_{1}$ and $\mathrm{S}_{2}$, respectively) was used as eluent. The quantitative recoveries were also found after 20 cycles of column pretreatment, indicating good chemical stability of the sorbents after prolonged usage. The effect of the eluant volume on the recovery of Ge(IV) was also investigated by keeping the $\mathrm{HCl}$ concentration at $1.0 \mathrm{M}$. The results showed that quantitative recoveries could be obtained with $1 \mathrm{~mL}$ of $1.0 \mathrm{M} \mathrm{HCl}$ (Figure 2, flow rate 1.0 and $1.3 \mathrm{~mL} / \mathrm{min}$ for $\mathrm{S}_{1}$ and $\mathrm{S}_{2}$, respectively).

\subsubsection{Effect of the Sample Volume and Dynamic Sorption Capacity}

In the analysis of water samples using solid phase extraction, the appropriate sample volume is among the key parameters to increase the recovery. Therefore, the sorption of Ge(IV) was studied with the sample volume ranging from 25 to $500 \mathrm{~mL}$ with a metal ion concentration of $25 \mathrm{mg} \cdot \mathrm{L}^{-1}$ (50 $\mathrm{mg}$ sorbent). The quantitative recoveries $(\mathrm{R}>95 \%)$ were obtained with a sample volume less than 300 and $250 \mathrm{~mL} \mathrm{Ge(IV)} \mathrm{for} \mathrm{S}_{1}$ and $\mathrm{S}_{2}$, respecttively. As described above, $1 \mathrm{~mL}$ of $1 \mathrm{M} \mathrm{HCl}$ was enough

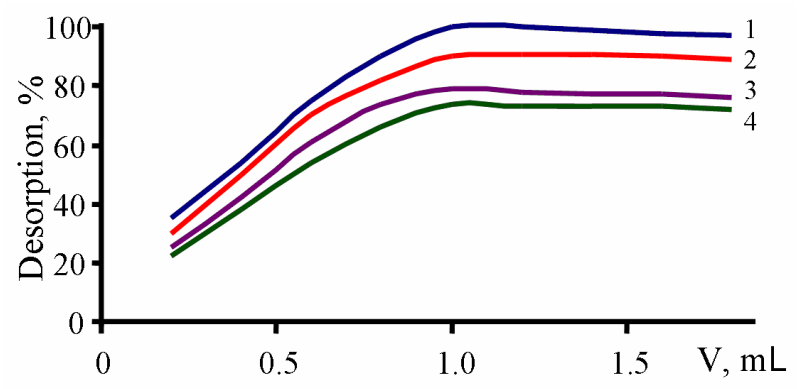

Figure 2. The influence of acids volume on desorption of Ge(IV) from $S_{1}$. Concentration of acid $=1 M$ constant. 1) $\mathrm{HCl}$; 2) $\mathrm{HClO}_{4}$; 3) $\mathrm{H}_{2} \mathrm{SO}_{4}$; 4) $\mathrm{HNO}_{3}$. 
to elute the analytes sorbed on sorbents, the enrichment (preconcentration) of Ge(IV) is about 190 and 160 for $S_{1}$ and $\mathrm{S}_{2}$, respectively.

The dynamic sorption capacity (Section 2.5) was determined under the optimal conditions ( $50 \mathrm{mg}$ sorbent, 25 $\mathrm{mL} 400 \mathrm{mg} \cdot \mathrm{L}^{-1} \mathrm{Ge}(\mathrm{IV})$, flow rate of 1.4 and $1.7 \mathrm{~mL} \cdot \mathrm{min}^{-1}$ for $S_{1}$ and $S_{2}$, respectively) and was found to be 152.2 and $127.1 \mathrm{mg} \cdot \mathrm{g}^{-1}$ for $\mathrm{S}_{1}$ and $\mathrm{S}_{2}$, respectively, what is higher than that of the previously studied chitosan resins $\left(101-106 \mathrm{mg} \cdot \mathrm{g}^{-1}\right)[9,28]$.

\subsection{Detection Limits and Precision}

The calibration curves under the chosen optimal chemical and flow conditions were plotted after the described above preconcentration process. The Beer's law was obeyed in the range of $1.2-18.2$ and $1.4-21.6 \mathrm{ng} \cdot \mathrm{mL}^{-1}$ for $S_{1}$ and $S_{2}$, respectively. In the determination without preconcentration, the linear range is observed in the range of $0.23-3.46 \mu \mathrm{g} \cdot \mathrm{mL}^{-1}$ (see Table 1). The limit of detection as determined from the intersection of the two extrapolated segments of the calibration graph was 0.9 and $1.1 \mathrm{ng} \cdot \mathrm{mL}^{-1}$ [relative standard deviation (RSD), 3.6 and $3.7 \%$ ] for $S_{1}$ and $S_{2}$, respectively. Thus, the found detection limit is much lower than that of the previously reported methods, generally around $\geq 7.2 \mathrm{ng} \cdot \mathrm{mL}^{-1}[3,8]$.

\subsection{Effect of the Interfering Species}

A most important characteristic of a sorbent is its response for the primary ion in the presence of other cations. The effect of the interfering species upon the sorption was investigated by the use of the proposed method at optimized conditions (see Experimental). The tolerance limits (w/w) less than $\pm 3 \%$ change in the per centage uptake of germanium ions was taken as being free from the interference. The experimental results indicated that alkaline and earth-alkaline metals, $\mathrm{Zn}(\mathrm{II})$, $\mathrm{Cd}(\mathrm{II}), \mathrm{Mn}(\mathrm{II}), \mathrm{Ni}(\mathrm{II}), \mathrm{Co}(\mathrm{II}), \mathrm{Al}(\mathrm{III}), \mathrm{Ga}(\mathrm{III}), \mathrm{In}(\mathrm{III})$, $\mathrm{Bi}(\mathrm{III}), \mathrm{Ti}(\mathrm{IV}), \mathrm{Zr}(\mathrm{IV}), \mathrm{Hf}(\mathrm{IV}), \mathrm{Sn}(\mathrm{IV})$ and $\mathrm{Pb}(\mathrm{IV})$ as well as anions had no significant effect on the separation and determination of Ge(IV) under the recommended conditions, and the most serious interference arose from $\mathrm{Cu}$ (II) and Fe(III) (Table 3). However, this interference can be completely eliminated by masking with $0.5 \mathrm{~mL}$ of $0.01 \mathrm{M}$ oxalic acid or citric acid. The above results also clearly demonstrate that the described herein sorbents show much better selectivity for the $\mathrm{Ge}^{4+}$ ion in comparison to the previously described ones, especially in view of such interfering ions as $\mathrm{Co}^{2+}, \mathrm{Mn}^{2+}, \mathrm{Ni}^{2+}, \mathrm{Zn}^{2+}$, $\mathrm{Sn}^{4+}$ and $\mathrm{PO}_{4}{ }^{3-}[2,3,27,30]$. The now described results also clearly indicate that the proposed sorbents can be applied for the column preconcentration/enrichment of germanium in the presence of high background matrix.
Table 3. Interference study of various co-existing metal ions (RSD < 5\%).

\begin{tabular}{|c|c|c|}
\hline \multirow{2}{*}{ Ion } & $\mathrm{S}_{1}$ & $\mathrm{~S}_{2}$ \\
\hline & {$[\mathrm{M}] /[\mathrm{Ge}(\mathrm{IV})]$} & {$[\mathrm{M}] /[\mathrm{Ge}(\mathrm{IV})]$} \\
\hline $\mathrm{Na}(\mathrm{I})$ & * & $*$ \\
\hline $\mathrm{K}(\mathrm{I})$ & $*$ & $*$ \\
\hline $\operatorname{Mg}(\mathrm{II})$ & $*$ & $*$ \\
\hline $\mathrm{Ca}(\mathrm{II})$ & $*$ & $*$ \\
\hline $\mathrm{Ba}(\mathrm{II})$ & * & * \\
\hline $\mathrm{Zn}(\mathrm{II})$ & 81 & 65 \\
\hline $\mathrm{Cd}(\mathrm{II})$ & 140 & 100 \\
\hline $\mathrm{Mn}(\mathrm{II})$ & 69 & 69 \\
\hline $\mathrm{Ni}(\mathrm{II})$ & 73 & 73 \\
\hline $\mathrm{Co}(\mathrm{II})$ & 74 & 48 \\
\hline $\mathrm{Cu}(\mathrm{II})$ & 4 & 2 \\
\hline $\mathrm{Al}(\mathrm{III})$ & * & * \\
\hline $\mathrm{Fe}(\mathrm{III})$ & 7 & 4 \\
\hline $\mathrm{Ga}(\mathrm{III})$ & 70 & 43 \\
\hline $\operatorname{In}(\mathrm{III})$ & 100 & 100 \\
\hline Bi(III) & 95 & 44 \\
\hline Ti(IV) & 60 & 30 \\
\hline $\mathrm{Zr}(\mathrm{IV})$ & 57 & 88 \\
\hline $\mathrm{Hf}(\mathrm{IV})$ & 57 & 84 \\
\hline $\mathrm{Sn}(\mathrm{IV})$ & 74 & 34 \\
\hline $\mathrm{Pb}(\mathrm{IV})$ & 65 & 65 \\
\hline $\mathrm{Cl}^{-}$ & 44 & 28 \\
\hline $\mathrm{SO}_{4}^{2-}$ & 100 & 100 \\
\hline $\mathrm{NO}_{3}^{-}$ & 77 & 77 \\
\hline $\mathrm{PO}_{4}^{3-}$ & 119 & 60 \\
\hline
\end{tabular}

${ }^{*}$ No interference.

\subsection{Application to Natural Samples}

The described herein preconcentration/determination of Ge was applied to samples of seawater and water obtained after oil pumping, and a comparison with the results of the reference atom-absorption analysis shows high accuracy and precision of the proposed methodology (Table 4).

Germanium in the studied water samples exists at several ten $\mathrm{ng} \cdot \mathrm{L}^{-1}$ levels $[3,28]$, thus, upon the treatment, it was concentrated by 160 or 190 fold. The known amounts of germanium were also spiked to water samples before 
Table 4. Analytical results of germanium in water samples after preconcentration $(n=5, P=0.95)$.

\begin{tabular}{|c|c|c|c|c|}
\hline Sample & $\begin{array}{l}\text { Added } \\
\mu \mathrm{g} \cdot \mathrm{L}^{-1}\end{array}$ & $\begin{array}{l}\text { Spectro-photometry } \\
\mu \mathrm{g} \cdot \mathrm{L}^{-1}\end{array}$ & $\begin{array}{l}\text { Atomic absorption analysis } \\
\qquad \mu \mathrm{g} \cdot \mathrm{L}^{-1}\end{array}$ & $\operatorname{RSD}(\%)$ \\
\hline \multirow{3}{*}{ Seawater } & 0 & $0.012 \pm 0.001$ & $0.011 \pm 0.001$ & $3.65(3.18)^{*}$ \\
\hline & 0.05 & $0.062 \pm 0.002$ & $0.061 \pm 0.001$ & $3.71(3.10)$ \\
\hline & 0.07 & $0.082 \pm 0.002$ & $0.081 \pm 0.002$ & $3.57(3.21)$ \\
\hline \multirow{3}{*}{$\begin{array}{c}\text { Water obtained } \\
\text { after oil } \\
\text { pumping }\end{array}$} & 0 & $0.028 \pm 0.002$ & $0.027 \pm 0.001$ & $3.73(3.04)$ \\
\hline & 0.05 & $0.078 \pm 0.001$ & $0.078 \pm 0.002$ & $3.64(3.16)$ \\
\hline & 0.07 & $0.098 \pm 0.003$ & $0.097 \pm 0.002$ & $3.62(3.14)$ \\
\hline
\end{tabular}

*RSD in atomic absorption spectrophotometry.

column pretreatment. A good agreement between the determined and added amount of germanium has been obtained. Excellent recoveries were reached, indicating the suitability of the sorbents for the selective collection of germanium from various water samples.

\section{Conclusion}

The obtained results demonstrate the efficiency of the chemically modified styrene-maleic anhydride copolymer sorbents towards selective quantitative sorption (separation) and preconcentration of germanium. The sorption is markedly influenced by the used complexing reagent (modificator), $\mathrm{pH}$ and flow rate. In contrast to some other reported sorbents (Table 1) the sudied sorbent shows better characteristics, i.e., being superior in terms of selectitity, detection limits and dynamic sorption capacity. The separation step results in an analytical sample which is relatively free of interferences of many ions. Favourable features of the described methodology are its low instrument and running costs, easy operation, and high sensitivity. It can be used in routine analysis and can be applied for the determination of ultra-trace germanium in a diversity of objects (environmental and industrial samples) without significant interaction from other cationic species present in the samples.

\section{Acknowledgements}

This work has been partially supported by the Foundation for Science and Technology (FCT), Portugal, and its PEst-OE/QUI/UI0100/2011 and "Science 2007" programs, as well as by the Baku State University, Azerbaijan. K.T.M. and M.N.K. express gratitude to the FCT for a post-doc fellowship and a working contract.

\section{REFERENCES}

[1] R. R. Moskalyk, "Review of Germanium Processing
Worldwide," Minerals Engineering, Vol. 17, No. 3, 2004 pp. 393-402. doi:10.1016/j.mineng.2003.11.014

[2] L. Xiang, X. Zhang, M. Lu, S. Qian and S. Mo, "Preconcentration of Ultra-Trace Germanium in Water Samples with Nano-Sized $\mathrm{TiO}_{2}$ Colloid and Determination by GFAAS with Colloid Sampling," Journal of Analytical Atomic Spectrometry, Vol. 27, No. 2, 2012, pp. 359-363. doi:10.1039/c1ja10275c

[3] L. Zhang, X. Guo, H. Li, Z. Yuan, X. Liu and T. Xu, "Separation of Trace Amounts of Ga and Ge in Aqueous Solution Using Nano-Particles Micro-Column," Talanta, Vol. 85, No. 5, 2011, pp. 2463-2469. doi:10.1016/j.talanta.2011.07.096

[4] D. Kalderis, E. Tsolaki, C. Antoniou and E. Diamadopoulos, "Characterization and Treatment of Wastewater Produced during the Hydro-Metallurgical Extraction of Germanium from Fly Ash," Desalination, Vol. 230, No. 5, 2008, pp. 162-174. doi:10.1016/j.desal.2007.11.023

[5] Y. Inukai, Y. Kaida and S. Yasuda, "Selective Separation of Germanium(IV) by Iminodiacetic Acid-Type Chitosan Chelating Resin," Analytical Sciences, Vol. 13, No. 3, 1997, pp. 339-344. doi:10.2116/analsci.13.339

[6] A. Harada, T. Tarutani and K. Yoshimura, "Spectrophotometric Determination of Germanium in Rocks after selective Adsorption on Sephadex Gel," Analytica Chimica Acta, Vol. 209, 1988, pp. 333-338. doi:10.1016/S0003-2670(00)84582-1

[7] G. Göktüŕk, M. Delzendeh and M. Volkan, "Preconcentration of Germanium on Mercapto-Modified Silica Gel," Spectrochimica Acta Part B: Atomic Spectroscopy, Vol. 55, No. 7, 2000, 1063-1071. doi:10.1016/S0584-8547(00)00232-9

[8] I. Nukatsuka, K. Takahashi, K. Ohzeki and R. Ishida, "Solid-Phase Spectrophotometric Determination of Germanium on a Membrane Filter after Collection Using Phenylfluorone and Zephiramine," Analyst, Vol. 114, No. 11, 1989, pp. 1473-1478. doi:10.1039/an9891401473

[9] Y. Inukai, T. Chinen, T. Matsuda, Y. Kaida and S. Yasuda, "Selective Separation of Germanium(IV) by 2,3Dihydroxypropyl Chitosan Resin," Analytica Chimica Acta, Vol. 371, No. 1-2, 1998, pp. 187-193. 


\section{doi:10.1016/S0003-2670(98)00313-4}

[10] Y. Inukai, Y. Tanaka, Y. Shiraishi, T. Matsuda, N. Mihara, K. Yamada, N. Nambu, O. Itoh, T. Doi, Y. Kaida and S. Yasuda, "Selective Separation of Germanium (IV) by $\mathrm{Di}(2$-hydroxyethyl)Amine-Type Cellulose Derivative," Analytical Sciences, Vol. 17, 2001, pp. i1117i1 1208 .

[11] J. Aznarez, P. Moneo, J. C. Vidad and F. Palacios, "Extraction-Spectrophotometric Determination of Germanium with Phenylfluorone in N,N-Dimethyl-Formamide," Analyst, Vol. 110, 1985, pp. 747-749.

[12] S. Nalini and T. V. Ramakrishna, "An Indirect Method for the Spectrofluorimetric Determination of Trace Amounts of Germanium after Extraction as an Ion Association Complex with Rhodamine B in the Presence of Chromotropic Acid," Talanta, Vol. 43, No. 9, 1996, pp. 1437- 1441. doi:10.1016/0039-9140(96)01906-6

[13] N. Nashine and R. K. Mishra, "Selective Extractive Spectrophotometric Determination of Germanium with $\mathrm{N}$ Hydroxy- $N, N$ '-Diphenylbenzamidine and Iodide," Analytica Chimica Acta, Vol. 285, No. 3, 1994, pp. 365-368. doi:10.1016/0003-2670(94)80077-4

[14] Y. Chen, R. Zhu, H. Qiong, F. Ji and X. Gu, "Determination of Trace Germanium by Spectrophotometry after Preconcentration on an Organic Solvent-Soluble Membrane," Michrochemical Journal, Vol. 64, No. 1, 2000, pp. 93-97. doi:10.1016/S0026-265X(99)00020-X

[15] X. Zhou, Z. J. Li, R. Yuan and H. Z. Liu, “A Novel Room Temperature Ionic Liquid Extraction Spectrophotometric Determination of Trace Germanium in Natural Water with Methybenzeneazo-Salicylfluorone," Analytical Letters, Vol. 39, No. 5, 2006, pp. 863-877. doi: $10.1080 / 00032710600605766$

[16] I. D. Brindle, M. E. Brindle and X. C. Le, "Preconcentration by Coprecipitation. Part 1. Rapid Method for the Determination of Ultra-Trace Amounts of Germanium in Natural Waters by Hydride Generation-Atomic Emission Spectrometry," Journal of Analytical Atomic Spectrometry, Vol. 6, No. 2, 1991, pp. 129-132. doi:10.1039/ja9910600129

[17] S. Jianbo, T. Zhiyong, T. Chunhua, C. Quan and J. Zexiang, "Determination of Trace Amounts of Germanium by flow Injection Hydride Generation Atomic fluorescence Spectrometry with On-Line Coprecipitation," Talanta, Vol. 56, No. 4, 2002, pp. 711-716. doi:10.1016/S0039-9140(01)00617-8

[18] A. E. Böyükbayram and M. Volkan, "Cloud Point Preconcentration of Germanium and Determination by Hydride Generation Atomic Absorption Spectrometry," Spectrochimica Acta Part B: Atomic Spectroscopy, Vol. 55, No. 7, 2000, pp. 1073-1080. doi:10.1016/S0584-8547(00)00233-0

[19] L. Zhang, H. Li, X. Liu and P. Kang, "Sorption Behavior of Germanium(IV) on Titanium Dioxide Nanoparticles," Russian Journal of Inorganic Chemistry, Vol. 57, No. 4, 2012, pp. 622-628. doi:10.1134/S003602361204016X

[20] J. D. Burton and J. P. Riley, "The Spectrophotometric Determination of Germanium with Phenylfluorone," Mikrochimica Acta, Vol. 47, No. 4, 1978, pp. 586-591.

\section{doi:10.1007/BF01221668}

[21] C. L. Leong, "Spectrophotometric Determination of Germanium with Catechol Violet and Cetyltrimethylammonium Bromide," Talanta, Vol. 18, No. 8, 1971, pp. 845848. doi:10.1016/0039-9140(71)80137-6

[22] V. Hernandis, L. Macia and J. V. Sala, "Spectrophotometric Determination of Germanium and Phosphorus in Siliceous Materials after Hydrofluoric Acid Distillation," Analyst, Vol. 112, No. 7, 1987, pp. 1007-1009. doi:10.1039/an9871201007

[23] H.-W. Gao and W.-G. Liu, "Spectrophotometric Investigation of Germanium Complex Solution with O-Chlorophenylfluorone and Determination of Trace Amounts of Germanium," Bulletin of the Korean Chemical Society, Vol. 21, No. 11, 2000, pp. 1090-1094.

[24] L. Zaijun, P. Jiaomai and T. Jan, "Spectrophotometric Method for Determination of Germanium in Foods with New Color Reagent Trimethoxylphenylfluorone," Analytica Chimica Acta, Vol. 445, No. 2, 2001, pp. 153-159. doi:10.1016/S0003-2670(01)01259-4

[25] L. Zaijun, Z. Xia, L. Huizhen and Y. Rui, "Novel Spectrophotometric Method for Determination of Trace Germanium in soils with Methylbenzene-Azosalicylfluorone Using Ultrasound-Assisted Leaching," Communications in Soil Science and Plant Analysis, Vol. 39, No. 3-4, 2008, pp. 461-474. doi:10.1080/00103620701826597

[26] H. Shen, Z. Wang and G. Xu, "Spectrophotometric Determination of Trace Amounts of Germanium in Minerals and Ores with 9-(O-Chlorophenyl)-2,6,7-trihydroxylxanthen-3-one in the Presence of Cetyltrimethylammonium Bromide," Analyst, Vol. 112, No. 6, 1987, pp. 887-889. doi:10.1039/an9871200887

[27] H.-J. Park and L. L. Tavlarides, "Germanium(IV) Adsorption from Aqueous Solution Using a Kelex-100 Functional Adsorbent," Industrial \& Engineering Chemistry Researc, Vol. 48, No. 8, 2009, pp. 4014-4021. doi:10.1021/ie801733d

[28] A. Sabarudin, T. Umemura and S, Motomizu, "Chitosan Functionalized with Di-2-Propanolamine: Its Application as Solid Phase Extractant for the Determination of Germanium in Water Samples by ICP-MS," Microchemical Journal, Vol. 99, No. 1, 2011, pp. 34-39. doi:10.1016/j.microc.2011.03.004

[29] C. Q. Sun, Q. Gao and L. L. Liu, “Adsorptive Stripping Measurements of Germanium(IV) in the Presence of Pyrogallol," Talanta, Vol. 42, No. 7, 1995, pp. 881-884. doi:10.1016/0039-9140(95)01501-2

[30] Q.-C. Chen, S.-F. Mou, Y. Yan and Z.-M. Ni, "Separation and Determination of Inorganic Germanium and B-CarBoxyethylgermanium Sesquioxide by High-Performance Ion-Exclusion Chromatography," Journal of Chromatography $A$, Vol. 789, No. 7, 1997, pp. 403-412. doi:10.1016/S0021-9673(97)00451-2

[31] F. A. Torralvo and C. Fernández-Pereira, "Recovery of Germanium from Real Fly Ash Leachates by Ion-Exchange Extraction," Minerals Engineering, Vol. 24, No. 1, 2011, pp. 35-41. doi:10.1016/j.mineng.2010.09.004

[32] J. P. Marco-Lozar, D. Cazorla-Amoro and A. Linares- 
Solano, "A New Strategy for Germanium Adsorption on Activated Carbon by Complex Formation," Carbon, Vol. 45, No. 13, 2007, pp. 2519-2528. doi:10.1016/i.carbon.2007.08.020

[33] O. S. Pokrovsky, G. S. Pokrovski, J. Schott and A. Galy, "Experimental Study of Germanium Adsorption on Goethite and Germanium Coprecipitation with Iron Hydroxide: X-Ray Absorption fine Structure and Macroscopic Characterization," Geochimica and Cosmochimica Acta, Vol. 70, No. 13, 2006, pp. 3325-3341. doi:10.1016/j.gca.2006.04.012

[34] V. Konsulov, A. Lyapova, G. Petrov, B. Eremieva and P. Saha, "Polymer Composite Material with Abrasive Features Containing Abrasive Waste," Journal of the University of Chemical Technology and Metallurgy, Vol. 43, No. 3, 2008, pp. 297-302.

[35] G. Karakus, A. F. Yenidunya, H. B. Zengin and Z. A. Polat, "Modification of Maleic Anhydride-Styrene Copolymer with Noradrenaline by Chemical and Enzymatic methods," Journal of Applied Polymer Science, Vol. 122, No. 4, 2011, pp. 2821-2828. doi:10.1002/app.34357

[36] M. Bruch, D. Mader, F. Bauers, T. Loontjens and R. Mulhaupt, "Melt Modification of Poly(Styrene-CoMaleic Anhydride) with Alcohols in the Presence of 1,3Oxazolines," Journal of Polymer Science Part A: Polymer Chemistry, Vol. 38, No. 8, 2000, pp. 1222-1231. doi:10.1002/(SICI)1099-0518(20000415)38:8<1222::AID -POLA5>3.0.CO;2-Z

[37] S. Kumari, D. Nigam, D. Agarwal and I. Nigam, "Synthesis and Characterization of Alkali-Modified StyreneMaleic Anhydride Copolymer for Dispersion of $\mathrm{TiO}_{2}$," Journal of Applied Polymer Science, Vol. 103, No. 5, 2007, pp. 3194-3205. doi:10.1002/app.25131

[38] F. Gökmeşe, E. Gökmeşe and A. O. Solak, "A New Adsorptive Square-Wave Stripping Voltammetric Method for the Trace Analysis of Germanium," Hacettepe Journal of Biology and Chemistry, Vol. 36, 2008, pp. 215-
221.

[39] J. A. C. Broekaert, "Analytical Atomic Spectrometry with Flames and Plasmas." Wiley, New York, 2002.

[40] S. Belkhiria, T. Meyer and A. Renken, "Styrene Maleic Anhydride Copolymerization in a Recycle Tubular Reactor: Reactor Stability and Product Quality," Chemical Engineering Science, Vol. 49, No. 24, 1994, pp. 49814990. doi:10.1016/0009-2509(94)00327-0

[41] B. Klumperman, "Mechanistic Considerations on Styrene-Maleic Anhydride Copolymerization Reactions," Polymer Chemistry, Vol. 1, No. 5, 2010, pp. 558-562. doi:10.1039/b9py00341j

[42] R. S. Rajput, D. C. Rupainwar and A. Singh, "A Study on Styrene Maleic Anhydride Modification by Benzoic Acid Derivatives and Dimethyl Sulfoxide," International Journal of ChemTech Research, Vol. 1, No. 4, 2009, pp. 915 919.

[43] V. C. Srivastava, I. D. Mall and I. M. Mishra, "Adsorption Thermodynamics and Isosteric Heat of Adsorption of Toxic Metal Ions onto Bagasse fly Ash (BFA) and Rice Husk Ash (RHA)," Chemical Engineering Journal, Vol. 132, No. 1-3, 2007, pp. 267-278. doi:10.1016/j.cej.2007.01.007

[44] R. A. Alieva, V. N. Veliev, S. Z. Gamidov and F. M. Chyragov, "Preconcentration of Molybdenum(VI) on Polymeric Adsorbents and Its Photometric Determination with Bis(2,3,4-trihydroxyphenylazo)benzidine in the Presence of 1,10-Phenanthroline," Journal of Analytical Chemistry, Vol. 63, No. 9, 2008, pp. 832-835. doi:10.1134/S1061934808090049

[45] K. T. Mahmudov, A. M. Maharramov, R. A. Aliyeva, I. A. Aliyev, M. N. Kopylovich and A. J. L. Pombeiro, "Ion Pairs of 5,5-Dimethyl-2-(2-hydroxy-3,5-disulfophenylhydrazo)cyclohexane-1,3-dione with Cationic SurfaceActive Substances as Analytical Reagent for Determination of Copper(II)," Analytical Letters, Vol. 43, No. 18, 2010, pp. 2923-2938. doi:10.1080/00032711003763665 